\title{
Study on Departure Tax Refund Scheme for Overseas Tourists in China \\ -- Take Hainan Province as an Example
}

\author{
Bai Yijun, Shen Zhaozhang* \\ College of Economy of Ji'nan University, Guangzhou 510632 \\ * Shen Zhaozhang is Corresponding Author
}

Keywords: Overseas tourists; shopping; Departure tax refund

\begin{abstract}
With the development of our economy, tourism has become the important pillar of the tertiary industry in our country, overseas tourists shopping drawback system as an important innovation of tax system. For Hainan tourism international popularity, give full play to Hainan's geographical and resource advantages, speed up the development of modern service industry, promoting the construction of international tourism island has important significance. Based on the inbound tourism market of Hainan province in China, with emphasis on the structure and inbound tourists consumption characteristics, the inbound tourism market analysis with shopping rebates research combining with our country existing pilot policy in Hainan were analyzed, to learn and to learn from experience, proposed our country implements the system need to be aware of problems and concrete Suggestions.
\end{abstract}

\section{Research background and significance}

Since reform and opening up, with the rapid development of the Chinese economy and constant increasing of the residents' disposable income, the third domestic industry, especially the tourism industry, is still in the initial stage of the development. However, the departure tax refund scheme for the overseas tourists plays a vital role in developing the domestic tourism, increasing the consumers' expenditure, improving the tourism income, and driving the propaganda and establishment of the international tourism image.

From the domestic economy operation in recent two years, the slow growth of the export and insufficient domestic demand becomes the bottleneck of restricting the continuous growth of our domestic economy. To implement the departure tax refund scheme for the overseas tourists can simulate them to increase the shopping and consumption in our country and then drive our domestic consumption demands. From the other hand, such system is favorable for the adjustment of our domestic industry structure. The tourism shopping consumes few resources. To promote the tourism shopping development through implementing the departure tax refund scheme, innovate and promote the consumption grading through the tax system, realize the employment growth and economic benefit has great significance on the overall development of our third domestic industry and the optimization of the industrial structure.

\section{Theoretical basis}

The concept of export rebate was firstly put forward by the mercantilist school when discussing the international trade in the initial stage of the capitalism development in the $15^{\text {th }}$ century. The Neo-classical economists raised the concept of export rebate from the viewpoint of driving the international trade development when expounding the international trade theory. However, the departure tax refund is an export rebate form developed and derived from the tourism industry among countries.

David Ricardo put forward that the bearer of the actual tax burden is the consumer when pointing out the tax shifting. The indirect tax of a country reflects the consumption policy and industry policy of the country to some extent. In the international trade, these policies should not be exerted to other countries with the goods export. If the indirect tax included in the export goods will not be returned, the tax will be shifted to the consumers of other countries, which increases the 
consumers' burden. It is unfair and unreasonable. So, the export rebate is necessary.

\section{Problems in the departure tax refund scheme for the overseas tourists in Hainan Province}

(1) The departure tax refund scheme lacks flexibility

On January 6th, 2015, to implement "studying and improving the departure tax refund scheme for the overseas tourists" specified in the State Council's Opinion about Promoting the Reform and Development of Tourism, it will implement the scale expansion to the requirements for the conditions over the country [1]. The Department of Finance released the notice about implementing the departure tax refund scheme policy for the overseas tourists [2]. "Management Method of Departure Tax Refund for Overseas Tourists in the Experimental Unit of Hainan” implemented in Hainan was canceled on June 2nd, 2015 [3]. Compared with the refund policy in Hainan, the tax category of our domestic departure tax refund is still added-value tax. The tax refund rate is still $11 \%$. The shopping amount is changed from previous RMB800 to RMB500. From the lowest consumption amount, our domestic standard is reduced. Its standard is higher than Singapore and America, but lower than EU and Australia. During the initial stage of the policy implementation, this standard positioned as a mean level is proper. However, the appropriateness of the tax refund rate should accept the checking from the market. Generally, the tax refund rate is consistent with the taxation rate in the world. However, during the actual taxation in China, although the tax rate for different articles is not the same, the tax refund date keeps $11 \%$. Therefore, some issues happen, such as too much or too little tax refund of some articles, insufficient flexibility of the tax refund rate, etc. With the expansion of the departure tax refund scale, our domestic refund rate is transformed to be reasonable tax refund zone according to the market and the actual adjustment.

(2) The tax refund has big limitation

According to the policy related to the tax refund, the tourisms applicable to get the refund should meet "the foreigners, Taiwanese, and compatriots from Hong Kong and Macau live in China continuously for less than 183 days", and also possess both overseas register and short-term residence. Therefore, it can be seen that, from the requirements for the census register and residence time, our domestic policy is stricter than other countries'. Our domestic tourists are not included in the tourists with the privilege of departure tax refund, which undoubtedly generates some limitation on the implementation of the policy. In addition, although the number of the overseas tourists is increasing year by year, most tourists are from Russia, Singapore, Japan and South Korea. Especially, in Japan, South Korea and Singapore, they have already implemented relatively mature departure tax refund and tax free policy. However, our current departure tax refund policy is difficult to reach the goal of accelerating the local tourism development and then improving the local economy.

Although once the tax refund policy is released, and it will reduce lots of taxation and pose great pressure on the finance, the number of our domestic consumers is so big. Besides, China has a great area and different regions have different tourism status. For some individual regions, it is feasible to refer to the experience from Australia, expand the scope of the tourists involved in the tax refund, and provide the same privilege to the tourists who have Chinese census register and live in foreign countries, and even the Chinese residents who depart for foreign countries, which will improve the local tourism.

(3) Complex tax refund procedure

The departure tax refund procedure China adopts is the form of tax refund form application. the process is that the store fill in the tax refund form, the customs verifies it and stamps, the branch conducts the tax refund, etc. The procedure is complex. It is not favorable for the government, stores, agents to conduct the tax. For the overseas tourists who have limit time and are urgent to go abroad, this procedure is quite inconvenient for them to conduct the tax refund. When the procedure is too complicated and the tourists get low tax refund, the tourists will give up the tax refund, which will affect the implementation of the tax refund policy.

(4) Immature tax-paying credit

Our domestic related policy stipulates that the tax refund stores should reach the standard of 
above level B of the taxpaying credit. Therefore, the limited number and category of the tax refund stores applying through the government restricts the tourists' scope and enthusiasm to some extent. However, at abroad, due to the mature credit system development, it does not make specific regulation on the credit rating of the designated stores. However, with the improvement of our domestic credit system, more stores will have the capability of implementing the departure tax refund, so as to provide convenience for the tourists to do shopping, and then achieve the goal of stimulating the consumption.

Our domestic tax refund procedure is basically the same as the way in the world: purchase the goods with tax refund, ask the tax refund store for the departure tax refund form and sales invoice, ask customs to verify and confirm it, ask for the tax refund from the agent, and the tax settled by the tax department. The disadvantage lies in that we do not adopt some innovative ways to improve the tax refund efficiency like other countries, such as getting tax refund at the same time of shopping. In future, with the development of our domestic credit system, and the mature of the taxation system, it is feasible to provide convenience to the tourists through establishing site tax refund points and self tax refund in large shopping malls.

\section{Suggestions on improving the departure tax refund scheme for the overseas tourists}

(1) Set flexible tax refund rate

The current tax refund rate for the overseas tourists is $11 \%$. The departure tax refund category is added-value tax. Internationally, the tax refund rate and the taxation rate formulated by the countries that implement the tax refund policy are the same. However, the added-value tax implemented by China at present adopts the mode of standard tax rate and first-level low tax rate. The standard tax rate is $17 \%$. At present, there are 5 levels of the goods export value-added tax refund: $5 \%, 9 \%, 11 \%$, $13 \%$, and $17 \%$. Therefore, some goods have too much tax refund but some have little. The tax refund lacks flexibility. With the expansion of the departure tax refund scale, "one-cut" tax refund issue becomes more obvious. Therefore, to guarantee the international taxation, optimize the departure tax refund policy, promote and establish reasonable departure tax refund scheme, it is quite significant to establish flexible tax refund rate according to current 5 levels of the current added-value tax rate.

(2) Promote the professional tax refund agencies

From Sweden in 1980s, the departure tax refund policy already has over 30 years of history, and gradually formed a set of relatively mature and standard management and operation mode. However, during the tax refund, as its verification and operation formalities are quite complicated for the government and tourists, to simplify the formalities and provide convenience, some professional tax refund agent servers come into being. In some sense, the history of the departure tax refund implementation is the development history of the tax refund agencies, while the tax refund service is a tourism finance intermediary service in essence.

Nowadays, regarding the tax refund procedure, China selects the mode of specified tax refund agencies, which is dominated by the government. Besides, we provide two ways: cash tax refund, and bank transfer tax refund. The currencies of the tax refund include Renminbi or main currencies with free flow. However, there are main three tax refund modes over the world: dominant professional agent companies, dominant retail stores, combination of government and professional agent companies. With the development of our domestic tourism in future, the tax refund service is increasing constantly. We can introduce foreign-funded agency tax refund institutions according the actual situation of the tourism market development. On one hand, these enterprises have mature tax refund experience and mature enterprise management mode. After introduction, it is favorable for driving the growth and development of our domestic local tax refund agencies. On the other hand, it is favorable for driving the consumption of the overseas tourists in China, just like the Chinese people prefer doing the payment through card with unionpay mark at abroad. The overseas tourists are more willing to apply familiar ways to pay. China can introduce the foreign-funded tax refund agencies and then drive the development of our domestic tourism and economy.

(3) Widely apply the electronic tax refund service 
New eTRS system was implemented in Singapore in May, 2011. Singapore becomes the first country to comprehensively apply the electronic tax refund service in the world. Compared with the previous old system through the tax refund form, the tourists no longer need to fill in the form for each article. Besides, when departure, they do not need to queue and apply for customs' verification, conduct the complicated tax refund formalities. The customs organization can conduct real-time searching and supervision on all application items at the backstage. Hu Qingxin holds that, such mode "greatly reduce the airport dispatched personnel's pressure on checking and stamping all application on the tax refund sheet, and it also reduces the work load of the taxation departments and agents for verifying the tax refund application form."

With the development of the modern technology and network, the old way for the tax refund application form will be gradually eliminated by the electronic tax refund that has high efficiency and superior service. To promote and apply the electronic tax refund service not only omits complex formalities, but also greatly improves the related departments' working efficiency, and provides great convenience for the taxation department and tourists. It reflects the concept of people first, which is the trend for our domestic tax refund way in future.

(4) Improve the tax-paying credit system

With the development of the e-payment, the credit-card consumption becomes most tourists' first choice for payment by virtue of its convenience and fastness. However, some tourists caused some immoral situations, such as malicious overdraft and credit fault, so as to meet their own consumption desire. To reduce the occurrence of such situation, it is necessary to ensure the sound development of the tourism shopping and improve the credit system construction, which is imperative action to ensure the sound development of the tourism industry.

The credit system is a behavior rule to restrict people's credit activities and relationship, and also guarantee and standardize the people's credit behavior. During the tax refund, the taxation supervision department should fully understand the financial organizations, tax refund stores and personal credit status, which is favorable for preventing the credit risk. The government should disclose and supervise the behaviors of breaching promises, constantly improve the credit system, credit risk management system and information disclosure system construction, and make the party that breaches the promises undertake the responsibility and punishment, so as to create good credit environment for the tax refund system.

From comprehensive perspective, our departure tax refund policy is relatively stable and proper. However, the policy is relatively simple: "one-cut" feature is obvious. Although it is convenient to be managed, if the tourists and merchants' benefit cannot be maintained, the experience quality of the tourists and merchants cannot be promoted in short term. Therefore, it is necessary to adjust the policies during the introduction, while the overall principle of the adjustment is based on the national situation and the related experience from foreign countries. In future, China can constantly improve our domestic departure tax refund policies according to the specific implementation status, establish departure tax refund system, and then drive the development of our domestic tourism shopping consumption and related industries.

\section{Conclusions}

The implementation of the departure tax refund policy is to innovate the Chinese tourism industry development policy to some extent. After Hainan implement this system, although it stimulates the development of the local tourism industry, it still has some issues, such as limited tax refund conditions, complicated tax refund procedures, immature taxpaying credit system, etc. In general, to implement the departure tax refund system can drive the development of the tourism shopping, and accelerate the consumption upgrading, improve the employment and economic benefit. Thus, it can promote the third industry and industry structure optimization, which has significant practical significance for the national economy. 


\section{References}

[1]FredericDimanche. The Louisiana Tax Free Shopping Program forInternational Visitors: A Case Study[J]. Journal of Travel Research.2003(41).P311-314.

[2]Pauline Sullivan, Mark A .Bonn,VerticaBhardwaj, Aim DuPont. Mexicannational cross-border shopping: Exploration of retail tourism[J]. Journal of Retailingand Consumer Services .2012 (19).P596-604.

[3]SubhayuBandyopadhyay, BaishaliMajumdar. Multilateral transfers, export taxation and asymmetry [J]. Journal of development economics. 2004(73).P115-725. 